\title{
A Rare Case of the Urinary Bladder: Small Cell Carcinoma
}

\author{
Mesanede Nadir Görülen Olgu: Küçük Hücreli Karsinom
}

\author{
(1) Enis Kervancıoğlu', (1) Ayhan Dirim', (1) Eda Yılmaz Akçay² \\ 'Başkent University Faculty of Medicine, Department of Urology, Ankara, Turkiye \\ ${ }^{2}$ Başkent University Faculty of Medicine, Department of Pathology, Ankara, Turkiye
}

\begin{abstract}
Small cell carcinoma generally originates from the lungs. However, rarely, it could be observed in organs other than the lungs. Primary small cell carcinoma of the bladder is a rare and aggressive disease and it generally presents itself with metastasis. Although there has not been a consensus on the method of treatment for this rare disease, multimodal treatment is recommended. In this study, we present long-term results of transurethral resection in a patient with non-muscle-invasive primary small cell carcinoma who refused additional treatments.

Keywords: Small cell carcinoma, Bladder tumor, Multimodal treatment
\end{abstract}

\section{Öz}

Küçük hücreli kanser çoğunlukla akciğer orijinlidir. Fakat nadiren akciğer dışı organlarda da görülebilir. Mesanenin primer küçük hücreli karsinomu nadir görülen ve çoğunlukla metastazlarla seyreden agresif bir hastalıktır. Nadir görülmeleri nedeni ile tedavisinde fikir birliği sağlanmamış olsa da multimodal tedavi önerilmektedir. Bu çalışmada ek tedavileri kabul etmeyen, kas invaziv olmayan primer küçük hücreli mesane kanserli bir olgunun sadece transüretral rezeksiyon sonrası uzun dönem sonuçları sunulmuştur.

Anahtar Kelimeler: Küçük hücreli kanser, Mesane tümörü, Multimodal tedavi

\section{Introduction}

Small cell carcinoma of the bladder is a very rare tumor accounting for less than $1 \%$ of all bladder cancers (1). It is much aggressive than the commonly seen types of cancers of the bladder and urothelial carcinoma and is associated with poor prognosis. Clinically, it has similarities with urothelial carcinoma. Patients with small cell carcinoma of the bladder typically present with macroscopic hematuria and rarely with signs of bladder irritation. Additionally, rarely, there may be signs of abdominal pain and urinary system obstruction. Although there has not been a consensus on the treatment because of its rarity, multidisciplinary approach, including radical cystectomy $(\mathrm{RC})$, chemotherapy and radiation therapy, is recommended to increase the chance of cure and life expectancy.

\section{Case Presentation}

This study was retrospective and patient approval was obtained. An 86-year-old female patient presented to our clinic with a bladder mass which was detected incidentally. Ultrasonography showed a 14x9 mm hyperechoic, vascularized solid lesion in the right lateral wall protruding into the lumen. Complete transurethral resection of bladder tumor (TURBT) was performed. Pathologic examination revealed lamina propria-invasive small cell carcinoma which was not invading the muscularis propria (Figures 1, 2). Thoracoabdominal computed tomography showed primary bladder small cell carcinoma with no lung pathology. Although there was muscle tissue in the specimen in pathologic examination, restaging-TUR was performed in order to do better staging after four weeks and no tumor formation was recognized in the pathologic examination. Additional treatment options, such as RC and radiotherapy were recommended to the patient by giving information on the aggressiveness of the disease, however, the patient did not accept any treatment. In the four-year follow-up of the patient who came to controls irregularly, no pathologic findings were detected in the control cystoscopies and systemic evaluations.

Correspondence: Enis Kervancıoğlu MD, Başkent University Faculty of Medicine, Department of Urology, Ankara, Turkiye

E-mail: enis14@yahoo.com ORCID-ID: orcid.org/0000-0003-3465-9092

Received: 17.04.2017 Accepted: 21.10.2017

Cite this article as: Kervancıoğlu E, Dirim A, Yılmaz Akçay E. A Rare Case of the Urinary Bladder: Small Cell Carcinoma. J Urol Surg 2018;5(3):203-205

๑Copyright 2018 by the Association of Urological Surgery / Journal of Urological Surgery published by Galenos Publishing House. 

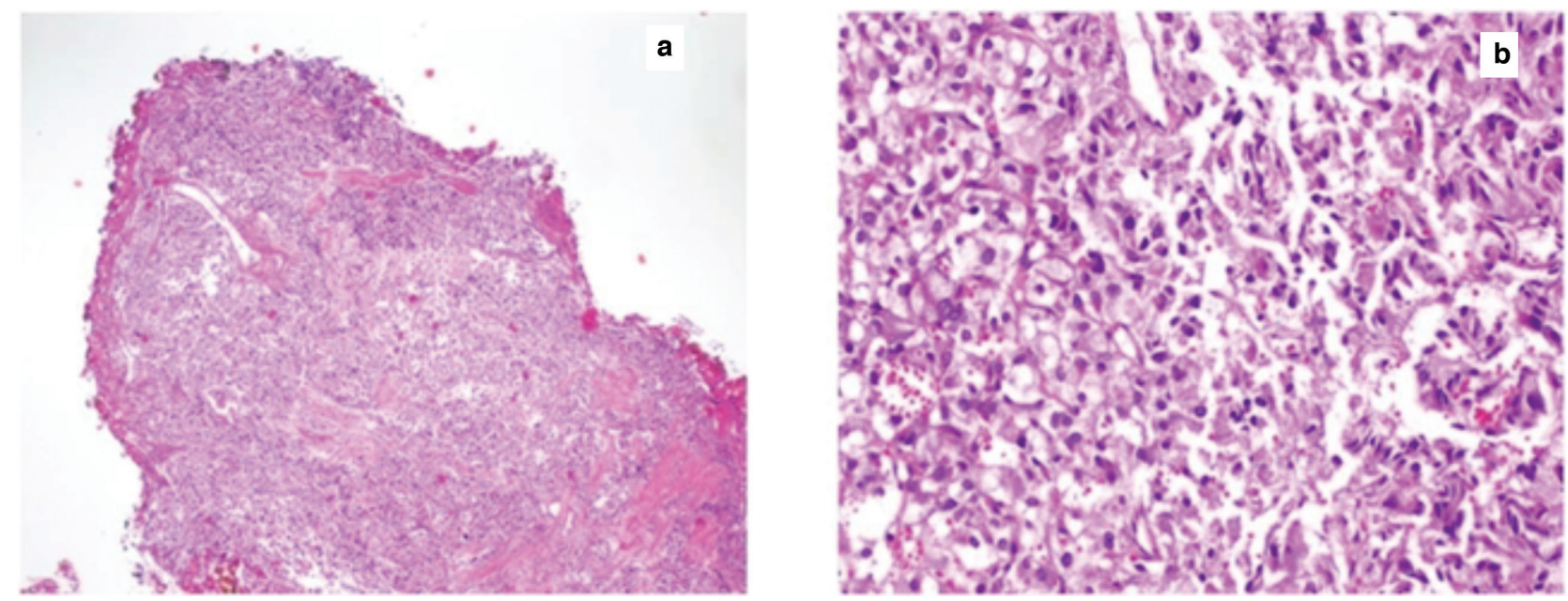

Figure 1. a) Small cell carcinoma of urinary bladder; tumor is composed of sheets and nests of atypical small cells (hematoxylin and eosin, 40x), b) Higher magnification of tumor cells with scant cytoplasm and hyperchromatic nucleus (hematoxylin and eosin, 200x)
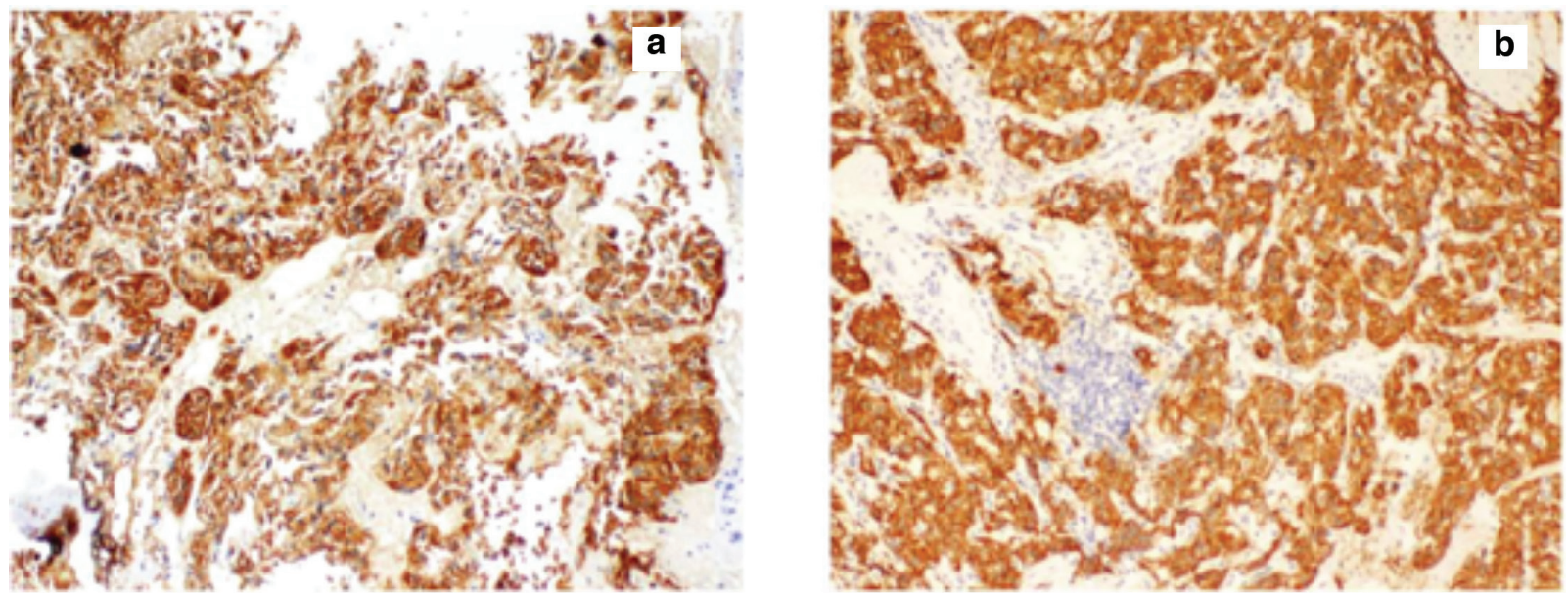

Figure 2. a) Immunostaining for synaptophysin is diffusely positive (100x), b) Immunostaining for chromogranin A is diffusely positive (100x)

\section{Discussion}

Small cell carcinoma of the bladder was first defined by Cramer et al. (2) in 1981. The ratio between male and female patients is $5 / 1$ and it is seen commonly in the $6^{\text {th }}$ decade of life (3). Pathologic diagnosis can generally be established via TURBT or immunohistochemical analysis of RC samples (4). Preoperative urine cytology may be useful for diagnosis, however this method has a low specificity (5).

It is much aggressive than the commonly seen urothelial carcinomas of the bladder and has poor prognosis. Nearly $40 \%$ of patients with small cell carcinoma present at an advanced stage (6). In one study, it has been reported that $66 \%$ of patients had lymph node metastasis detected during RC (3). Our case belongs to the rare group of patients with non-muscle invasive disease followed up with re-TUR evaluation. The explanation for the absence of the expected aggressive features can be made based on this situation.
There is no standard treatment for small cell carcinoma of the bladder. Local treatment options are TURBT, RC and radiation therapy as for urothelial carcinoma. High recurrence and poor survival rates have been reported for the disease which cannot be controlled with only TURBT (7). According to the experiences of Mayo Clinic, if there is not any metastasis, RC should be performed for patients with bladder small cell carcinoma. Systemic chemotherapy should be planned for patients with metastasis. Chemotherapy following RC is not indicated for patients with stage 2 disease but is considered for those with stage 3 and 4 disease (8). Neoadjuvant chemotherapy and $\mathrm{RC}$ combination as multimodal therapy has been reported to provide longer survival when compared with $\mathrm{RC}$ alone (9). On the other hand, Cheng et al. (3) have reported that there was no difference in 5-year survival between patients treated with $\mathrm{RC}$ and those who received no treatment.

In some selected patients with localized low-stage bladder small cell carcinoma, TURBT, radiotherapy and partial cystectomy can 
be performed. RC is thought to be the best method to totally remove the mass, however, it only improves survival in patients with localized tumor (10).

As a result, since it is an aggressive disease and is rarely seen, there is no standard treatment approach to the management of small cell carcinoma of the bladder. It is seen that in muscle invasive disease, there must be $\mathrm{RC}$ and in metastatic disease, multimodal treatment is required in the light of recent studies. However, in rare situations like our case, non-muscle-invasive disease may occur. There have not been many studies in the literature regarding non-muscle-invasive bladder small cell carcinoma. We believe that our study will be useful in the topic. However, it is obvious that large-scale studies are needed.

\section{Ethics}

Informed Consent: Consent form was filled out by participant.

Peer-review: Externally peer-reviewed.

\section{Authorship Contributions}

Surgical and Medical Practices: E.K., A.D., Concept: E.K., Design: E.K., Data Collection or Processing: E.K., E.Y.A., Analysis or Interpretation: A.D., Literature Search: E.K., Writing: E.K.

Conflict of Interest: No conflict of interest was declared by the authors

Financial Disclosure: The authors declared that this study received no financial support

\section{References}

1. Blomjous CE, Vos W, De Voogt HJ, Van der Valk P, Meijer CJ. Small cell carcinoma of the urinary bladder. A clinicopathologic, morphometric, immunohistochemical, and ultrastructural study of 18 cases. Cancer 1989;64:1347-1357.

2. Cramer SF, Aikawa $M$, Cebelin $M$. Neurosecretory granules in small cell invasive carcinoma of the urinary bladder. Cancer 1981;47:724-730.

3. Cheng L, Pan CX, Yang XJ, Lopez-Beltran A, MacLennan GT, Lin H, Kuzel TM, Papavero V, Tretiakova M, Nigro K, Koch MO, Eble JN. Small cell carcinoma of the urinary bladder: a clinicopathologic analysis of 64 patients. Cancer 2004;101:957-962.

4. Hou $\mathrm{CP}$, Lin $\mathrm{YH}$, Chen $\mathrm{CL}$, Chang $\mathrm{PL}$, Tsui $\mathrm{KH}$. Clinical outcome of primary small cell carcinoma of the urinary bladder. Onco Targets Ther 2013;6:11791185.

5. Takada S, Yoshikawa M, Hosokawa Y, Hayashi Y, Fujimoto K, Hirao Y. Small cell carcinoma of the urinary bladder detected by urinary cytology: a case report. Hinyokika Kiyo 2010;56:173-175.

6. Koay EJ, Teh BS, Paulino AC, Butler EB. A Surveillance, Epidemiology, and End Results analysis of small cell carcinoma of the bladder: epidemiology, prognostic variables, and treatment trends. Cancer 2011;117:5325-5333.

7. Celik O, Ekin G, Ipekci T, Budak S, Ilbey YO. Diagnosis and treatment in primary bladder small cell carcinoma: Literature review. Arch Ital Urol Androl 2016;88:52-55.

8. Choong NW, Quevedo JF, Kaur JS. Small cell carcinoma of the urinary bladder. The Mayo Clinic experience. Cancer 2005;103:1172-1178.

9. Siefker-Radtke AO, Dinney CP, Abrahams NA, Moran C, Shen Y, Pisters LL, Grossman HB, Swanson DA, Millikan RE. Evidence supporting preoperative chemotherapy for small cell carcinoma of the bladder: a retrospective review of the M. D. Anderson cancer experience. J Urol 2004;172:481-484.

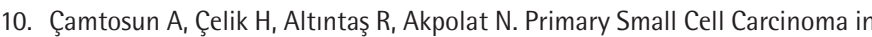
Urinary Bladder: A Rare Case. Case Rep Urol 2015;2015:789806. 